\title{
Effects of Supply Chain Integration on Competitive Advantage and Organizational Performance: A Case of Food Complex Industries in Asella town
}

\author{
NafyadTolaAbebe \\ (Lecturer, Researcher), Department of Logistics and Supply chain Management, College of Business and \\ Economics, Arsi University \\ PO Box: 193, Asella, Ethiopia \\ LemaTeshomeBeyecha \\ (Lecturer and Researcher), Department of International trade and Investment Management, College of Business \\ and Economics, Arsi University \\ PO Box: 193, Asella, Ethiopia \\ Adenech Mengistu Gemeda \\ (Lecturer and Researcher), Department of Management, College of Business and Economics, Arsi University, \\ PO Box: 193, Asella, Ethiopia
}

\begin{abstract}
This research was sponsored by Arsi University.
\end{abstract}
\begin{abstract}
s
The main objective of this research was to investigate the effects of supply chain integration on competitive advantage and organizational performance in the food complex industries in Asella town. A cross-sectional survey research design was employed in this study. The population of interest comprised of all suppliers (farmers and farmers cooperatives), employees, customers, wholesalers and retailers were involved and multistage sampling was employed and 234 sample size was used. Structured questionnaire was used to collect primary data. Data was collected and analyzed using SPSS package, Descriptive statics, inferential statics and correlation to describe and analyze the extent of supply chain integration and its effects on competitive advantage and organizational performance. The study revealed that supply chain integration (supply chain responsiveness, strategic partnership, supply chain information, customer relationships) positively affects the competitive advantage and organizational performance. The study also shows that food complex industries supply chain integration were poor in improving company's competitive advantage and organizational performance. The study recommends that the actors of the food complex industries should foster and customize of managing their supply chains as this has a direct influence on competitive advantage and organizational performance.
\end{abstract}

Keywords: supply chain integration, competitive advantage, organizational performance

DOI: $10.7176 /$ IEL/11-2-03

Publication date:June $30^{\text {th }} 2021$

\section{INTRODUCTION}

Supply chain management has become an important focus of competitive advantage and best strategies to enhance performance for business organization. The understanding and practicing of supply chain management (SCM) has become an indispensable prerequisite for staying competitive in the global rivalry and for enhancing organizational performance. The management of supply chain study emphasizes how to maximize the overall value of the firm by better using and deployment of resources across the whole of the firm (Levi (2004). Effective supply chain management is important to build and sustain competitive advantage and organizational performance in product and services of the firms. Gunasekaran and Ngai, (2004); Sufian (2010) stated that the performance of supply chain was influenced by managing and integrating key element of information into their supply chain. According to Sufian (2010) to achieve a competitive advantage and better performance, supply chain management strategy need support the business strategy. Sahay and Mohan (2003) proposed that Supply chain management practices be measured in four dimensions, and they are; alignment between supply chain strategies with business strategies, supply chain integration, partnerships, and information technologies. As Hoover et al (2001) stated having competitive products and the right supply chain for the average customer is not enough in the current business environment. The supply chain has to be right for the customer as well. Customer relationships combining with a firm's operation and customers' operation, makes up a demand -supply chain.

The integration of supply chain strategy, operations, technology, people, business and processes is crucial for survival and competitive edge in the current digital age and this is not important only within a firm but also across extended enterprises (Awad \& Nassar, 2010). Supply chain management is one of the most strategic functions of an organization which can be exploited to gain a sustainable organizational growth in the marketplace. It is 
imperative now for organizations to search for new business paradigms to gain an organizational growth in the marketplace. Level of Information sharing, strategic alliance with suppliers and customer relationship is now an indicator of organizational growth as well as a "challenge" for organizations in the marketplace. Information has enabled firms to reengineer activities and practices for being competitive in the marketplace.

One of the primary challenges of food complex industries in developing countries were how to integrate their supply chain practice activities ( strategic supplier partnership, supply chain responsiveness, customer relationship, level of information sharing and postponement) to successful secure a reliable internal operation capability. An organization's internal operation is the critical cornerstone in creating superior supply chain performance before embarking on external coordination. To gain competitive advantage and improve organizational performance over rapid change, internal processes must be flexible and integrated in responding to market changes. This requires the flexibility of frequent changes to accommodate mass customization and thus improve customer responsiveness (Lambert and Cooper, 2002).

In Ethiopia business organizations are running traditional and fragmented business activity. So, in this research we conceptualizes and develops four dimensions of SCM practice (strategic supplier partnership, supply chain responsiveness, customer relationship, level of information sharing) and competitive advantage and organizational performance of food complex industries in Asella town.

\subsection{Objectives of the Study}

The general objective of this study was to investigate the effects of supply chain integration on competitive advantage and organizational performance of food complex industries in Asella town

\subsubsection{Specific objectives}

- To see the integration of Supply Chain function of food complex industries in the study area

- To test the effects of supply chain integration on competitive advantage of food complex industries

- To test the effects of supply chain management practice on organizational performance of food complex industries

\section{Literature review}

\subsection{Supply Chain Management Practices of agro-processing industries}

Supply chain management practices are viewed from a variety of different perspectives and multi-dimensional concept. Li et al (2005) defined SCM practices as the set of activities undertaken in an organization to promote effective management of its supply chain. There are several different definitions for supply chain related to integration (Mentzer, et al., 2001) such as "the concept of supply chain management is all about integration" (Pagell, 2004). Integration of supply chain management is considered to be strategic as well as important for operational excellence (Bechtel \& Jayaram, 1997; Christopher, 1997; Lambert, Cooper, \& Pagh, 1998; Frohlich \& Westbrook, 2001; Zailani \& Rajagopal, 2005). It has been proved through research and practice that more integration of supply chain leads to better performance (Stock, Greis, \& Kasarda, 2000; Droge, Jayaram, \& Vickery, 2004; Gimenez \& Ventura, 2003). It has also been argued by Cagliano, Caniato, \& Spina (2006) that there is a positive impact of supply chain integration on the business performance.

Specifically, Trkman \& Groznik (2006) has discussed certain benefits of supply chain integration as it enabled the organization to do effective business renovation and business process modeling that increased the efficiency and profitability of a business. Different benefits of supply chain integration were also presented by several other researchers. Li, Ragu-Nathan, Ragu-Nathan, \& Rao (2006) stated that supply chain integration enabled the organization to gain a sustainable competitive advantage in the marketplace and it enhances organizational performance by enabling it to reach its goals and objectives effectively and efficiently. Rosenzweig, Roth, \& Jr. (2003) state that supply chain integration enables an organization to satisfy the needs and wants of target customers "superiorly" relative to competition and thus customer satisfaction/loyalty increases. This provides a sustainable competitive advantage and improve organizational performance to the organization. The following figure summarizes the benefits associated with supply chain integration: 


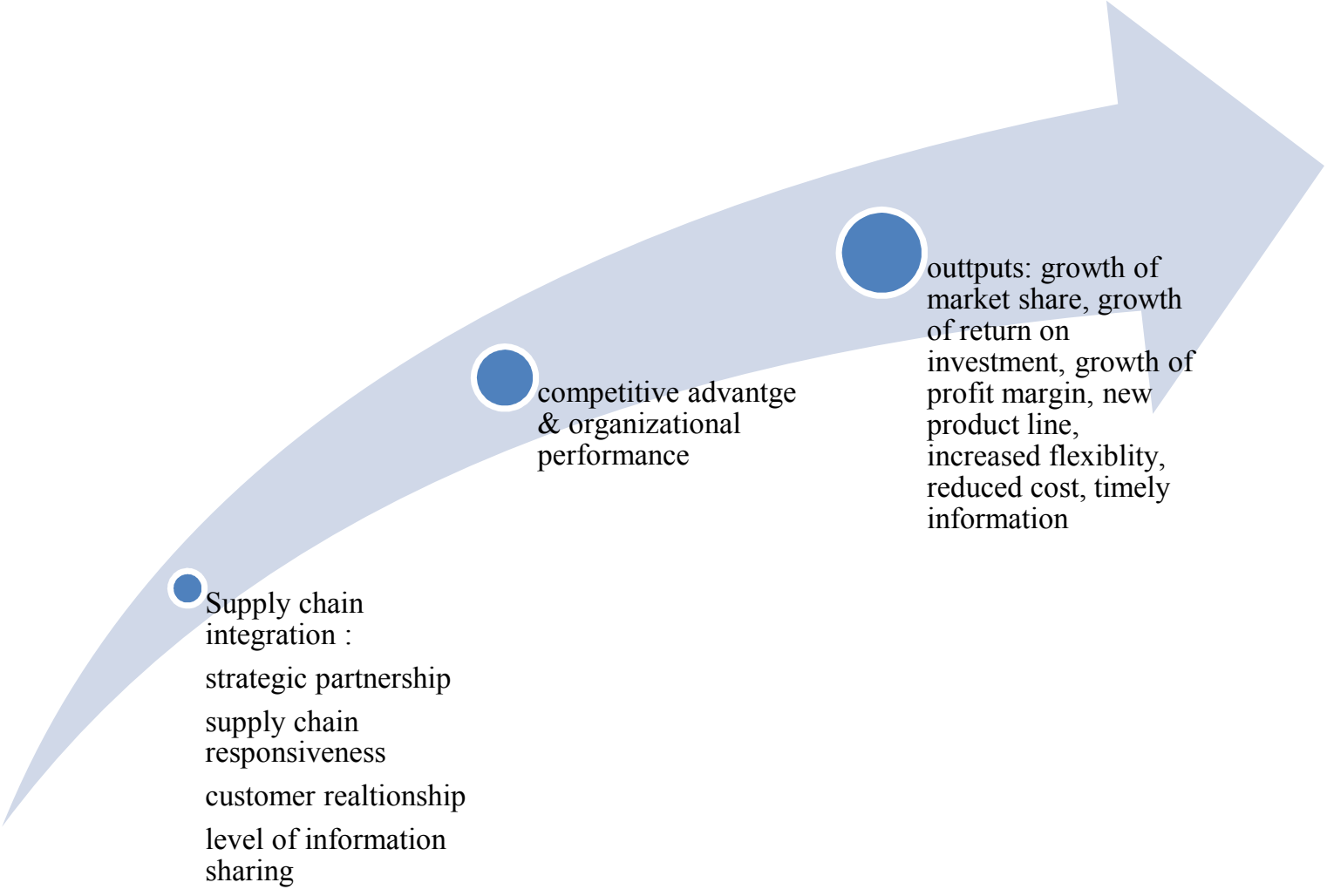

\section{Methods and materials}

In this research cross-sectional research method was used as the researchers wants to explore the correlation among the identified variables with the firms' competitive advantage and organizational performance. In this methodology, the researcher's poses questions to willing participants, summarized and analyzed them and finally inference is made for the population form the drawn. In order to generate relevant data for the study, the researcher used both primary and secondary data sources. These data were collected through structured questionnaire from the targeted respondents of this study. It is not feasible to collect data for the entire statistical population, a sample, which is a representative of the population, was drawn from the registered suppliers, customers, wholesalers, retailers, and permanent employees of each food complex industries. In Asella there were three food complex industries (Chilalo Food complex, Arsi Ketar food complex and Biherawi food complex). The participants were proportionally selected from all actors of supply chain. Accordingly, from the target population, this study were target to registered suppliers (124), registered customers (207) factory employees (172), registered distributors (25) and registered retailers (34). The researchers were used multistage sampling techniques. $1^{\text {st }}$ strata (supplier, customer, employee and distributors/retailers), $2^{\text {nd }}$ purposive sampling to select premium suppliers and customers, and $3^{\text {rd }}$ simple random sampling techniques to undertake this study and to participate all actors equally. Collected data were analyzed using descriptive and inferential statics. Sample size was statistically drawn:

$$
n=\frac{N}{1+N(e)^{2}}
$$

\section{Where;}

$\mathrm{N}=$ Size of total population, $\mathrm{n}=$ is the desired Sample size, $\mathrm{e}=$ is the estimated standard error which is $5 \%$ for $95 \%$ confidence level (the limit of tolerable error $5 \%$ ), $n=562 / 1+562\left(0.05^{2}\right)=234$.

Figure 2: strata

\begin{tabular}{|l|l|l|l|l|l|}
\hline Sn. & Strata & Chilalo food complex & Arsi ketar food complex & Biherawi Food Complex & Total \\
\hline 1 & Suppliers & 54 & 34 & 36 & 124 \\
\hline 2 & Customers & 77 & 60 & 70 & 207 \\
\hline 3 & Employees & 92 & 38 & 42 & 172 \\
\hline 4 & Distributors & 11 & 6 & 8 & 25 \\
\hline 5 & Retailers & 14 & 8 & 12 & 34 \\
\hline & Total & 248 & 146 & 168 & 562 \\
\hline
\end{tabular}




\section{Analysis and Discussions}

\subsection{Descriptive Analysis}

\begin{tabular}{|l|l|l|}
\hline & Description & Respondents \\
\hline $\mathbf{1}$ & Sample & $\mathbf{2 3 4}$ \\
\hline $\mathbf{2}$ & Questionnaire Distributed & $\mathbf{2 1 8}$ \\
\hline $\mathbf{3}$ & Questionnaire Returned & $\mathbf{2 0 8}$ \\
\hline $\mathbf{4}$ & Response rate & $\mathbf{8 8 . 9 \%}$ \\
\hline $\mathbf{5}$ & Usable response & $\mathbf{2 0 8}$ \\
\hline
\end{tabular}

Source: Field Survey, 2019/20

Response rate is the total number of respondents who participated in the study and out of the total questionnaires distributed i.e.218, out of which 208 were participated in the survey. The percentage of response rate was $88.9 \%$. According to Saunders et al., (2009) a response rate above $60 \%$ is good, and above $70 \%$ is very good.

Table 4.2: Supplier partnership, customer relationship, level of information sharing and competitive advantage

Suppliers partnership

Std.

Mean Deviation

The level of supply chain integration are poor

$3.76 \quad 0.211$

\begin{tabular}{|l|l|l|l|}
\hline There are no well-established trust, problem sharing solving mechanism and skills transfer & 3.46 & 0.344
\end{tabular} among partners

\begin{tabular}{ll|l|l}
\hline Critical item suppliers are not considered as strong strategic partners and key team member & 3.45 & 0.097
\end{tabular} of the whole supply chain.

\begin{tabular}{|c|c|c|}
\hline Key suppliers are not aligned with planning issues of the organization. & 4.13 & 0.377 \\
\hline No Clear guidelines and procedures used for monitoring alliances & 3.92 & 0.443 \\
\hline Doesn't Fills customer orders as accurately and promptly as required & 3.81 & 0.303 \\
\hline More and better products information are not provided to customers & 3.59 & 0.328 \\
\hline Technical assistance and trainings are not offered to various users of the products. & 3.61 & 0.458 \\
\hline \multicolumn{3}{|l|}{ Customers relationship } \\
\hline $\begin{array}{l}\text { The factory is not Starts customer relationships from the requirement of the customer needs } \\
\text { and accordingly plan, design and develop products and services. }\end{array}$ & 3.75 & 0.097 \\
\hline $\begin{array}{l}\text { Not Obtains feedback from customers and modify products and services to meet the } \\
\text { requirement }\end{array}$ & 3.92 & 0.311 \\
\hline Not Strives and launches new products and services to the customers & 2.03 & 0.077 \\
\hline Fills customer orders as accurately and promptly as required & 3.91 & 0.3103 \\
\hline More and better products information are provided to customers & 3.49 & 0.480 \\
\hline \multicolumn{3}{|l|}{ level of Information sharing } \\
\hline $\begin{array}{l}\text { No Invests in IT to connect the people both within the company as well as across the supply } \\
\text { chain. }\end{array}$ & 4.05 & 0.937 \\
\hline People are not willing to use and share information within and across the supply chain. & 4.24 & 0.967 \\
\hline $\begin{array}{l}\text { Online connections (EDI, internets etc.) are not widely used within as well as across supply } \\
\text { chain members }\end{array}$ & 4.20 & 0.965 \\
\hline $\begin{array}{l}\text { Information regarding monitoring of orders, materials, schedules, inventories are not } \\
\text { electronic }\end{array}$ & 4.25 & 0.979 \\
\hline Online information about customers are not tracked & 4.26 & 0.098 \\
\hline Not Uses online systems to achieve operating efficiency & 3.88 & 0.410 \\
\hline \multicolumn{3}{|l|}{ Organizational performance } \\
\hline Growth of market share & 3.51 & .418 \\
\hline Growth of return on investment & 4.51 & .502 \\
\hline Growth of sales volume & 3.50 & .502 \\
\hline Growth of profit margin & 4.50 & .502 \\
\hline Improved competitive advantage & 3.72 & .502 \\
\hline
\end{tabular}




\section{Competitive advantage}

An organization is capable of competing against major competitors based on low price.

An organization able is not compete based on quality.

3.51

An organization offer products that are not highly reliable.

4.51

An organization is not capable of providing on time, the type and volume of product required $\quad 4.50 \quad 502$ by customer(s).

An organization is capable of introducing new products faster than major competitors.

3.72

Source: own survey 2019/20

Results of the finding suggests that most of the respondent's reported that key suppliers are not aligned with planning issues of the organization their respective company as shown by a mean score of 4.13 , respondents also reported that there is poor supply chain integration as an integral part of suppliers partnership to a very large extent, no well-established trust, problem sharing solving mechanism and skills transfer among partners, critical item suppliers are not considered as strong strategic partners and key team member of the whole supply chain, , no clear guidelines and procedures used for monitoring alliances, doesn't Fills customer orders as accurately and promptly as required, more and better products information are not provided to customers, technical assistance and trainings are not offered to various users of the products, that strategic partnership were not strong to the expected level in their respective companies as shown by a mean score of 3.76, 3.46,3.45, 3.92,3.81,3.59, and 3.61 respectively. This indicates that strategic partnership with the suppliers was poor in improving company's organizational performance.

The table 4.2 shows that how customer relationship affects the competitive advantage and organizational performance of the firms by communicating with, development and implementation of different programs to secure the best level of satisfaction of the customers. As it was shown the company Strives and launches new products and services to the customers as suggested by the respondents who agreed to this, this was shown by the mean score of 2.03, but the factory is not Starts customer relationships from the requirement of the customer needs and accordingly plan, design and develop products and services, not Obtains feedback from customers and modify products and services to meet the requirement, no fill customer orders as accurately and promptly as required, and no more and better products information are provided to customers to manage customers were strategic partner to their business as it was shown by the mean score of 3.85, 3.92, 3.91, and 3.49 respectively. This indicates the company strives only to launch new products to the customers but there were poor customer relationship management.

The results of the table 4.2 indicates that to what extent the company uses technology to exchange information with business actors at least cost. As it was shown online information about customers were not tracked at point of sale as shown by mean score of 4.26, low Investments in IT to connect the people both within the company as well as across the supply chain, some actors are not willing to use and share information within and across the supply chain, Online connections (EDI, internets etc.) are not widely used within as well as across supply chain members, Information regarding monitoring of orders, materials, schedules, inventories are not electronic, Not Uses online systems to achieve operating efficiency to enable people, functions, and organizations to work together as a team along the supply chain as it was shown by the mean score of 4.05, 4.24, 4.20, 4.25, and 3.88 respectively. This implies that there were poor technology adoption to secure competitive advantage and organizational performance in coordination within and across organization activities, but usage of appropriate information technology would improve supply chain responsiveness, save ordering time, and enable to achieve efficiency.

The table 4.2 reals that how an organization is able to create a defensible position over its competitors, as it was shown above an organization is not able to compete based on quality and cannot provide products on time, needed volume, type of products needed by the customers, provides products not highly reliable as shown by mean score of 4.514 .5 , and 3.5 respectively, but an organization competes against major competitors by low price and capable of introducing new products faster than new competitors as it was shown by mean score of 3.51 and 3.72 respectively. This indicates that poor level of supply chain integration affects competitive advantage of the organizations in terms of product quality, on time delivery, needed volume of products and products reliability. As today's competition is moving from "among organizations" to "between supply chains", more and more organizations are increasingly adopting supply chain integration in the hope of reducing supply chain costs and securing competitive advantage. The findings of this research support the view that supply chain integration can have discernible impact on competitive advantage.

The table 4.2 reveals that organizational performance measured by marketing performance and financial performance as it was shown above the organization has high growth of return on investment as it was shown by 4.51, respondents also respond that growth of market share, growth of sales volume, growth of profit margin and improved competitive advantage as it was shown by a mean score of $3.51,3.5,4.5$, and 3.72 respectively.

This indicates that level of supply chain integration affects organizational performance of the organizations in terms of return on investment, sales volume, profit margin, and competitive advantage. The findings of this 
research support the view that supply chain integration can have discernible impact on organizational performance.

\subsection{Correlation Analysis}

Table 4.4 shows the correlation between independent variables (supplier strategic partnership, customer relationship, supply chain responsiveness and level of information sharing) and dependent variables (competitive advantage and organizational performance of the firm) were positive. Strategic supplier partnership had a correlation of $.871^{* *}, \mathrm{p}<0.01$ with organizational performance, customer relationship had a correlation of $.676^{* *}$, $\mathrm{p}<0.01$ with organizational performance, supply chain responsiveness had a correlation of $.741^{* *}, \mathrm{p}<0.01$ with organizational performance, level of information sharing average had a correlation of $.540^{*}, \mathrm{p}<0.01$ with an organizational performance. Which mean that the respondents are more likely to evaluate strategic supplier partnership, Customer relationship, supply chain responsiveness and level of information sharing were positively affects the organizational performance of the firm. From this strategic partnership and supply chain responsiveness factors has strongest correlation with organizational performance as shown by statics results of 0.871 and .741 respectively. Customer relationship factors has medium correlation with organizational performance as it was shown by statically result of 0.676 and level of information sharing has a weak correlation with organizational performance as it was shown by statics result of 0.540 .

Table4.4 also shows the correlation between independent variables and the second dependent variable (competitive advantage) were positive. Strategic supplier partnership had a correlation of $.782^{* *}, \mathrm{p}<0.01$ with competitive advantage, customer relationship had a correlation of $.681^{* *}, \mathrm{p}<0.01$ with competitive advantage, supply chain responsiveness had a correlation of $.652^{* *}, p<0.01$ with competitive advantage, level of information sharing average had a correlation of $.761^{*}, \mathrm{p}<0.01$ with competitive advantage and organizational performance had a correlation of $.564^{* *}, \mathrm{p}<0.01$ with competitive advantage. Which mean that the respondents are more likely to evaluate strategic supplier partnership, Customer relationship and level of information sharing were positively affects the competitive advantage of the firm. From this strategic partnership and level of information sharing factors has strongest correlation with competitive advantage as shown by statics results of $0.782,0.761$ respectively. Customer relationship and supply chain responsiveness factors has medium correlation with competitive advantage as it was shown by statically result of 0.681 and competitive advantage has a weak correlation with organizational performance as it was shown by statics result of 0.564 .

Table 4.3: The correlation between independent and dependent variables

\begin{tabular}{|c|c|c|c|c|c|c|c|}
\hline & & $\begin{array}{l}\text { Competitive } \\
\text { advantage }\end{array}$ & $\begin{array}{l}\text { Organizational } \\
\text { performance }\end{array}$ & $\begin{array}{l}\text { Strategic } \\
\text { Partnership } \\
\text { average }\end{array}$ & $\begin{array}{l}\text { customer } \\
\text { relationship } \\
\text { average }\end{array}$ & $\begin{array}{l}\text { level of } \\
\text { information } \\
\text { sharing average }\end{array}$ & $\begin{array}{l}\text { Supply chain } \\
\text { responsiveness }\end{array}$ \\
\hline \multirow[t]{3}{*}{$\begin{array}{l}\text { Competitive } \\
\text { advantage }\end{array}$} & $\begin{array}{l}\text { Pearson } \\
\text { Correlation }\end{array}$ & 1 & $.691^{* *}$ & $.771^{* *}$ & $.676^{* *}$ & $.540^{* *}$ & $.652^{* *}$ \\
\hline & Sig. (2-tailed) & .000 & & .000 & .000 & .000 & .000 \\
\hline & $\mathrm{N}$ & 208 & 208 & 208 & 208 & 208 & 208 \\
\hline \multirow[t]{3}{*}{$\begin{array}{l}\text { organizational } \\
\text { performance }\end{array}$} & $\begin{array}{l}\text { Pearson } \\
\text { Correlation }\end{array}$ & $.564^{* *}$ & 1 & $.871^{* *}$ & $.822^{* *}$ & $.660^{* *}$ & $.741^{* *}$ \\
\hline & Sig. (2-tailed) & .000 & .000 & & .000 & .000 & .000 \\
\hline & $\mathrm{N}$ & 208 & 208 & 208 & 208 & 208 & 208 \\
\hline \multirow{3}{*}{$\begin{array}{l}\text { Strategic } \\
\text { Partnership } \\
\text { average }\end{array}$} & $\begin{array}{l}\text { Pearson } \\
\text { Correlation }\end{array}$ & $.782^{* *}$ & $.871^{* *}$ & 1 & $.822^{* *}$ & $.660^{* *}$ & $.722^{* *}$ \\
\hline & Sig. (2-tailed) & .000 & .000 & & .000 & .000 & .000 \\
\hline & $\mathrm{N}$ & 208 & 208 & 208 & 208 & 208 & 208 \\
\hline \multirow{3}{*}{$\begin{array}{l}\text { customer } \\
\text { relationship } \\
\text { average }\end{array}$} & $\begin{array}{l}\text { Pearson } \\
\text { Correlation }\end{array}$ & $.681^{* *}$ & $.676^{* *}$ & $.822^{* *}$ & 1 & $.653^{* *}$ & $.553^{* *}$ \\
\hline & Sig. (2-tailed) & .000 & .000 & .000 & & .000 & .000 \\
\hline & $\mathrm{N}$ & 208 & 208 & 208 & 208 & 208 & 208 \\
\hline \multirow{3}{*}{$\begin{array}{l}\text { level of } \\
\text { information } \\
\text { sharing average }\end{array}$} & $\begin{array}{l}\text { Pearson } \\
\text { Correlation }\end{array}$ & $.761^{* *}$ & $.540^{* *}$ & $.660^{* *}$ & $.653^{* *}$ & 1 & $.812^{* *}$ \\
\hline & Sig. (2-tailed) & .000 & .000 & .000 & .000 & .000 & .000 \\
\hline & $\mathrm{N}$ & 208 & 208 & 208 & 208 & 208 & 208 \\
\hline \multirow[t]{3}{*}{$\begin{array}{l}\text { Supply chain } \\
\text { responsiveness }\end{array}$} & $\begin{array}{l}\text { Pearson } \\
\text { Correlation }\end{array}$ & $.652^{* *}$ & $.741^{* *}$ & $.722^{* *}$ & $.453^{* *}$ & .812 & 1 \\
\hline & Sig. (2-tailed) & .000 & .000 & .000 & .000 & .000 & .000 \\
\hline & $\mathrm{N}$ & 208 & 208 & 208 & 208 & 208 & 208 \\
\hline
\end{tabular}

**. Correlation is significant at the 0.01 level (2-tailed). 


\subsection{Inferential Statistics}

In this study a multiple linear regression model was implemented to identify the relationship between the three independent variables (level of information sharing average, customer relationship average, Strategic supplier Partnership average and supply chain responsiveness average) and the dependent variables which is the competitive advantage and organizational performance of the firm. The researchers applied the statistical package for social sciences (SPSS) to code, enter and compute the measurements of the multiple regressions for the study. Table 4.4: Modell summary and coefficients of variables

\begin{tabular}{|c|c|c|c|c|c|c|}
\hline \multirow{3}{*}{$\begin{array}{l}\text { Model } \\
\text { summary }\end{array}$} & \multirow{2}{*}{$\begin{array}{l}\mathbf{R} \\
.912\end{array}$} & \multirow{2}{*}{$\begin{array}{l}\mathbf{R} \\
\text { square } \\
.826\end{array}$} & \multirow{2}{*}{$\begin{array}{l}\text { Adjusted } \\
\text { R square } \\
.812\end{array}$} & \multicolumn{2}{|c|}{$\begin{array}{l}\text { Std. Error of the } \\
\text { Estimate }\end{array}$} & \multirow{2}{*}{$\begin{array}{l}\text { Durban- } \\
\text { Witson } \\
2.208 \\
\end{array}$} \\
\hline & & & & \multicolumn{2}{|l|}{.1111} & \\
\hline & Model & \multicolumn{2}{|c|}{$\begin{array}{l}\text { Unstandardized } \\
\text { Coefficients }\end{array}$} & $\begin{array}{l}\text { Standardized } \\
\text { Coefficients }\end{array}$ & $\mathrm{t}$ & \\
\hline \multirow{6}{*}{ Coefficients } & Variables & B & Std. Error & B(Beta) & & Sig \\
\hline & Constant & 1.021 & 0.54 & & 19.401 & .000 \\
\hline & $\begin{array}{l}\text { Strategic } \\
\text { partnership factors } \\
\left(\mathrm{X}_{1}\right)\end{array}$ & 0.762 & 0.023 & 0.087 & 1.315 & .000 \\
\hline & $\begin{array}{l}\text { Customer } \\
\text { relationship factors } \\
\left(\mathrm{X}_{2}\right)\end{array}$ & .423 & 0.021 & 0.975 & 14.824 & .000 \\
\hline & $\begin{array}{l}\text { Level of } \\
\text { information sharing } \\
\left(\mathrm{X}_{3}\right)\end{array}$ & 0.614 & 0.017 & 0.214 & -4.297 & .000 \\
\hline & $\begin{array}{l}\text { Supply chain } \\
\text { responsiveness (x4) }\end{array}$ & 0.531 & 0.014 & 0.976 & 14.732 & .000 \\
\hline
\end{tabular}

The $\mathrm{R}$ column represents the value of $R$, the multiple correlation coefficient. $\mathrm{R}$ is considered to be one measure of the quality of the prediction of the dependent variable; organizational performance. A value of 0.912 , in this case, indicates a good level of prediction. The ' $\mathrm{R}$ square' column represents the $\mathrm{R} 2$ (also called the coefficient of determination), which is the proportion of variance in the dependent variable that can be explained by the independent variables (technically, it is the proportion of variation accounted for by the regression model above and beyond the mean model). In this case a value 0.826 means that the model independent variables explain $82.6 \% \%$ of the variability of the dependent variable, organizational performance while the remaining $17.4 \%$ of the variation of the dependent variable was explained by other factors which were not included in the model.

In Table 4.4 above values under B column indicates that the value of constant term and the estimated coefficients of independent variables in the multiple regression model that used as a measurement of organizational performance.

There were two hypothesis in this research study. The null-hypothesis was stated as the Supply chain integration do not affect the competitive advantage and organizational performance of food complex industries, and it was tested at a 5\% level of significance. Accordingly, the result revealed that Supply chain integration do play a significant role in fostering the competitive advantage and organizational performance as the null hypothesis was rejected and the alternative hypothesis which stated the Supply chain integration do affect the competitive advantage and organizational performance was accepted as illustrated in Table 4.4 and 4.5. The unstandardized coefficients B column, indicated that the estimate of coefficients of the independent variables in the multiple regression equation as indicated below in the following form.

Model 1, when organizational performance is dependent Variable $\left(\mathrm{Y}_{1}\right)$

$\mathrm{Y}_{1}=\alpha+\beta_{1} \mathrm{X}_{1}+\beta_{2} \mathrm{X}_{2}+\beta_{3} \mathrm{X}_{3}+\beta_{4} \mathrm{X} 4+\mathrm{e}$

Organizational performance $\left(\mathrm{Y}_{1}\right)=1.021+.0 .762\left(\right.$ strategic partnership- $\left.\mathrm{X}_{1}\right)+0.423\left(\right.$ customer relationship $\left.-\mathrm{X}_{2}\right)+$ 0.614 (level of information sharing- $\mathrm{X}_{3}$ ) +0.531 (supply chain responsiveness- $\mathrm{X}_{4}$ )

The multiple regression equation in this study could be summarized in the following equation form.

$$
Y=1.021+0.762 X 1+0.423 X 2+0.614 X 3+0.531
$$

Table 4.4 above further shows that, all the explanatory variables included in the above regression equation in this study can significantly explain at $95 \%$ confidence level to the variation on the dependent variable. The standardized beta coefficient column shows the contribution that an individual variable makes to the model. In this study the first and second highest influence on the organizational performance were by strategic partnership and level of information sharing factors, with Beta value of 0.762, and 0.614, respectively. On the contrary, customer relationship factors and supply chain responsiveness with a beta value of 0.423 and 0.531 respectively was the lowest predictor of the organizational performance. 
Table 4.5: Modell summary and coefficients of variables

\begin{tabular}{|c|c|c|c|c|c|c|}
\hline \multirow{3}{*}{$\begin{array}{l}\text { Model } \\
\text { summary }\end{array}$} & $\mathrm{R}$ & $\begin{array}{l}\mathrm{R} \\
\text { square }\end{array}$ & $\begin{array}{l}\text { Adjusted } \\
\text { R square }\end{array}$ & \multicolumn{2}{|c|}{$\begin{array}{l}\text { Std. Error of the } \\
\text { Estimate }\end{array}$} & $\begin{array}{l}\text { Durban- } \\
\text { Witson }\end{array}$ \\
\hline & .872 & .816 & .803 & \multicolumn{2}{|l|}{.1111} & 2.208 \\
\hline & Model & \multicolumn{2}{|c|}{$\begin{array}{l}\text { Unstandardized } \\
\text { Coefficients }\end{array}$} & $\begin{array}{l}\text { Standardized } \\
\text { Coefficients }\end{array}$ & $\mathrm{t}$ & \\
\hline \multirow{6}{*}{ Coefficients } & Variables & $\mathrm{B}$ & Std. Error & $\mathrm{B}$ (Beta) & & Sig \\
\hline & Constant & 1.054 & 0.54 & & 18.401 & .000 \\
\hline & Strategic partnership factors $\left(\mathrm{X}_{1}\right)$ & 0.662 & 0.023 & 0.087 & 1.425 & .000 \\
\hline & Customer relationship factors $\left(\mathrm{X}_{2}\right)$ & .461 & 0.021 & 0.975 & 13.824 & .000 \\
\hline & Level of information sharing $\left(\mathrm{X}_{3}\right)$ & 0.524 & 0.017 & 0.214 & -3.297 & .000 \\
\hline & Supply chain responsiveness (x4) & 0.751 & 0.014 & 0.976 & 13.732 & .000 \\
\hline
\end{tabular}

Model 2, when competitive advantage is dependent variable $\left(\mathrm{Y}_{2}\right)$

$\mathrm{Y}_{2}=\alpha+\beta_{1} \mathrm{X}_{1}+\beta_{2} \mathrm{X}_{2}+\beta_{3} \mathrm{X}_{3}+\beta_{4} \mathrm{X} 4$ e..............

Competitive advantage $\left(\mathrm{Y}_{2}\right)=1.054+.0 .662$ (strategic partnership- $\left.\mathrm{X}_{1}\right)+0.461\left(\right.$ customer relationship $\left.-\mathrm{X}_{2}\right)+$ 0.524 (level of information sharing- $\mathrm{X}_{3}$ ) +0.751 (supply chain responsiveness)

The multiple regression equation in this study could be summarized in the following equation form.

$$
Y=1.054+0.662 X 1+0.461 X 2+0.524 X 3+0.751 X 4
$$

Table 4.5 above further shows that, all the explanatory variables included in the above regression equation in this study can significantly explain at $95 \%$ confidence level to the variation on the dependent variable. The standardized beta coefficient column shows the contribution that an individual variable makes to the model. In this study the first and second highest influence on the competitive advantage were by supply chain responsiveness and strategic partnership with Beta value of 0.751, and 0.662, respectively. On the contrary, customer relationship factors and level of information sharing with a beta value of 0.0423 and 0.531 respectively were the lowest predictor of the competitive advantage.

\subsubsection{Analysis of Variance (ANOVA)}

The F-ratio in the ANOVA table 4.5 tests whether the overall regression model is a good fit for the data. The table shows that the independent variables statistically significantly predict the dependent variable.

\section{Table 4.3: Analysis of Variance (ANOVA)}

\begin{tabular}{ll|r|r|r|r|r} 
Model & & Sum of Squares & df & Mean Square & F & Sig. \\
\hline 1 & Regression & 7.877 & 3 & 2.666 & 215.736 & $.000^{\mathrm{b}}$ \\
\cline { 2 - 7 } & Residual & 1.548 & 118 & .012 & & \\
\cline { 2 - 8 } & Total & 9.545 & 129 & & & \\
\hline
\end{tabular}

As illustrated in Table 4.5, there regression model shows all the independent variables explains the variability in the dependent variables significantly at $\alpha=0.01$ as p-value was 0.000 . The regression analysis also yields an Fstatistic where if the calculated F-value is less than the critical or tabled F-value, the prediction will be accepted. In this study, the significance value is .0001 which is less that 0.5 thus the model is statistically significant in predicting supplier strategic partnership, customer relationship, supply chain responsiveness, level of information sharing, competitive advantage and organizational performance.

\section{Conclusions}

The findings of this study indicates that supply chain management practice (supply chain responsiveness, strategic partnership, level of information sharing, customer relationships) affects the companies' competitive advantage and organizational performance. The standardized beta coefficient shows the contribution that an individual variable makes to the model. In this study the first and second highest influence on the organizational performance were by strategic partnership and level of information sharing factors in the first model. In the second model the first and second highest influence on the competitive advantage were by supply chain responsiveness and strategic partnership. On the contrary, customer relationship factors and level of information sharing with were the lowest predictor of the competitive advantage.

\subsection{Recommendations of the Study}

From the results of this study the researchers recommends that the supply chain actors food complex industries ( suppliers, cooperatives, producers, wholesalers, retailers, employees, customers) in the upstream and downstream should give focus to strategies that can integrate their supply chain function better, as this has a direct influence on competitive advantage and organizational performance. The study recommends that information communication technology should be fully developed and utilized by the firms. Firms should formulate policy framework and guidelines, which will facilitate the linkages of the joint supply chain function to ensure efficient and effective utilization of resources within supply chain to assure competitive advantage and organizational 
performance.

\section{Acknowledgement}

Authors would like to acknowledge Arsi University, Research and Publication directorate, for funding or proving financial support of ETB 48,200/ USD1332.

Conflict of interest: None

\section{References}

Adhaya Z, (2013): Supply Chain Management Practices of Agricultural Sector Parastatals In Kenya: School of Business of The University of Nairobi," KCA Journal of Business Management: Vol. 5, Issue 2, Nairobi, Kenya.

Awad, H. A., \& Nassar, M. O. (2010a). Supply Chain Integration: Definition and Challenges. Retrieved September 1, 2011, from International Association of http://www.iaeng.org/publication/IMECS2010/IMECS2010 pp405-409.pdf

Bechtel, C., \& Jayaram, J. (1997). Supply chain management: a strategic perspective. The International Journal of Logistics Management, 8 (1), 15-34.

Bowen M., Morara M. and Mureiti S. (2009): "Management of Business Challenges among Small and Micro Enterprises in Nairobi-Kenya"; KCA Journal of Business Management: Vol. 2, Issue 1, Nairobi, Kenya.

Burgess, K., Singh, P.J. \& Koroglu, R (2006), "Supply chain management: a structured literature review and implication s for future research", International Journal of operations and Production Management, Vol.26 No. 7 pp. $703-29$

Cagliano, R., Caniato, F., \& Spina, G. (2006). The linkage between supply chain integration and manufacturing improvement programmes. International Journal of Operations \& Production Management, 26 (1), 283-299.

Chatterjee S, -. Regression analysis by example. (2006) 4th ed. / edn. Hoboken, N.J. :: Wiley-Interscience.

Chong, A.Y.L, Ooi, K.B. \& Sohal, A. (2009), "The Relationship between Supply chain Factors and Adoption of E- collaboration Tools": An Empirical Examination”. International Journal of production Economics, Vol. 122 No1, pp. 150-60

Christopher, M. (1997). Marketing Logistics. Oxford: Butterworth-Heinemann.

Cooper, M. C., Lambert, D. M., \& Pagh, J. D. (1997). Supply Chain Management: More than a New Name for Logistic. International Journal of Logistics Management, 8 (1), 1-14.

DeVellis RF. Scale development: theory and applications. (1991) Newbury Park, Calif. Sage.

DiStefano C, Zhu M, Mîndrilă D. Understanding and Using Factor Scores: Considerations for the Applied Researcher. Practical Assessment, Research \& Evaluation (2009) Volume 14

Dramm J. Results-Driven Approach to Improving Quality and Productivity. State \& Private Forestry (undated):16

Droge, C., Jayaram, J., \& Vickery, S. (2004). The effect of internal versus external integration practices on timebased performance and overall firm performance. Journal of Operations Management, 22 (6), 557-573.

Fraza V. SCM for small distributors. Industrial Distribution (2000) 89:81. Fraza V. SCM for small distributors. Industrial Distribution (2000) 89:81.

Frohlich, M. T., \& Westbrook, R. (2001). Arcs of integration: an international study of supply chain strategies. Journal of Operations Management, 19, 185-200.

Gimenez, C., \& Ventura, E. (2003). Supply chain management as a competitive advantage in the Spanish grocery sector. The International Journal of Logistics Management, 14 (1), 77-88.

Gunasekaran A, Patel C, Tirtiroglu E. Performance measures and metrics in a supply chain environment. International Journal of Operations and Production Management 2001; 21 (1/2):71-87.

Lambert DM, Cooper MC. Issues in supply chain management. Industrial Marketing Management (2000) 29:65, 66.

Lambert, D., Cooper, M., \& Pagh, J. (1998). Supply chain management: implementing issues and research opportunities. The International Journal of Logistics Management, 9 (2), 1-18.

Lambert, D.M, \& cooper.M.C (2002), "Issues in supply chain Management: Industrial Marketing Management, Vol, 34, pp. 107-24

Lee P, Yeung A, Cheng T. Supplier alliances and environmental uncertainty: An empirical study. International Journal of Production Economics (2009) 120:190.

Lee, H.L. (2000). Creating value through supply chain integration. Supply Chain Management Review, 4(4), 3036.

Li, S., Ragu-Nathan, B., Ragu-Nathan, T., \& Rao, S. S. (2006). The impact of supply chain management practices on competitive advantage and organizational performance. Omega, 34 (2), 107-124.

Mentzer, J., Dewitt, W., Keebler, J., Min, S., Nix, N., Smith, C., et al. (2001). Defining supply chain management. Journal of Business Logistics, 22 (2), 1-25. 
Min, S \& Mentzer, J.T (2004), “Developing and measuring supply chain concept,” Journal of Business Logistics, Vol.25No. 1, pp.63-99

Mugenda, O.M, \& Mugenda A.G (2003) Research methods: Quantitative and Qualitative approaches, African center of technology studies, Nairobi

Oliver, R., \& Webber, M. (1982). Supply chain management: logistics catches up with strategy. In M. Christopher, Logistics: The Strategic Issues (pp. 63-75). London: Pitman.

Ott L. An introduction to statistical methods and data analysis. (2001) 5th ed. edn. Australia; Pacific Grove, CA: Duxbury/Thomson Learning.

Pagell, M. (2004). Understanding the factors that enable and inhibit the integration of operations, purchasing and logistics. Journal of Operations Management, 22 (5), 459-487.

Rosenzweig, E. D., Roth, A. V., \& Jr., J. W. (2003). The influence of an integration strategy on competitive capabilities and business performance: An exploratory study of consumer products manufacturers. Journal of Operations Management, 21 (4), 437-456.

Stevens J. Applied multivariate statistics for the social sciences. (2002) 4th ed. edn. Mahwah,N.J. :: Lawrence Erlbaum Associates.

Stevens J. Applied multivariate statistics for the social sciences. (2002) 4th ed. edn. Mahwah, N.J.: Lawrence Erlbaum Associates.

Stock, G., Greis, N., \& Kasarda, J. (2000). Enterprise logistics and supply chain structure: the role of fit. Journal of Operations Management, 18 (5), 531-547.

Stuart, I., McCutcheon, D., Handfield, R., McLachlin, R., \& Samson, D. (2002). Effective case research in operations management: a process perspective. Journal of Operations Management, 20 (5), 419-433.

Tan, K. C. (2002). Supply chain management: Practices, concerns, and performance issues, Journal of Supply Chain Management, 38(1), 42-53.

Tracey, M., Lim, J.S., \& Vonderembse, M.A. (2005), the impact of supply chain management capabilities on business performance. Supply chain management: an international Journal, 10(3), 179-191.

Trkman, P., \& Groznik, A. (2006). Measurement of Supply chain integration benefits. Interdisciplinary Journal of Information, Knowledge, and Management, 1, 37-45.

Van Hoek RI. Measuring the unmeasurable-measuring and improving performance in the supply chain. SupplyChain Management 1998; 3(4):187-92.

Zailani, S., \& Rajagopal, P. (2005). Supply chain integration and performance: US versus East Asian companies. Supply Chain Management: An International Journal, 10 (5), 379-393.

Zou, H \& Benton W.C Jr (2007), "supply chain practice and information sharing," Journal of operation management, Vol 25No, 6, pp, 1348-65 